\section{AB0038 RHEUMATOID ARTHRITIS WITH SACROLITIS}

WW Morof, DK Kapofka, UB Brych, AT Tarka, RK Kocur. Reumatology, Silesia Hospital, Ustron, Poland

\subsection{6/annrheumdis-2001.1003}

Background What is the form of rheumatoid arthritis (RA) with asymmetric peripheral arthritis, sacroilitis and present rheumatoid factor (RF).

Objectives The aim of this work is a presentation rhematoid arhritis considering an illness begining, increase's dynamics of RF and sacroilitis.

Methods 41 cases of RA sacroilitis and increased RF were retrospectively analysed considering clinical, radiological and laboratory indices.

Results Monoarthritis appeared as often as not in knee-joints (42\%), talus-joints (44\%) and single joints of hand (41\%). Radiological asymmetry of sacroilitis was found in $27 \%$. there appeared 42\% (10) atlantoodontoid subluxations from among 24 X-ray pictures. In $49 \%$ of analysed a degree of arthritis changes was twice as advanced in peripheral joints than sacroiliac joints. In $22 \%$ the progression of radiological changes correlated with RF Titre. In laboratory research: there was increase dynamics of RF in 51\%. In 71\% Cases (15 examined) ascertained high circulating immuno complexes. in 26\% (38 examined) ascertained increased gamma globulins. Other inflammation parameters were also high. Among accompanied disorders important were: hypertension blood in 51\%, cystes of renals in $27 \%$ (26 examined).

Conclusion

- RA with sacroilitis and present RF is an aggressive and systemic form.

- It begins tricky with single joints.

- Progression of destructive changes is most advanced in peripheral joints and cervical vertebral column than sacroiliac joints.

- Symptomatically often accompany vasculitis and gammapathia.

\section{AB0039 INVESTIGATION OF INTRARENAL HEMODYNAMICS IN PATIENTS WITH RHEUMATOID ARTHRITIS}

BF Nemtsov, GA Postnikova, OV Simonova. Internal Medicine, Kirov State Medical Academy, Kirov, Russia

\subsection{6/annrheumdis-2001.1004}

Background Impairment of the kidneys in case of rheumatoid artritis (RA) is one of the most severe complications and results in unfavourable prognoses.

Objectives To investigate intrarenal hemodynamics (IRHD) in patients with diverse clinical forms of RA.

Methods 43 RA patients were studied according to ACR criteria. Of them, there were 36 females and 7 males. The mean age was 47.8 years. The average duration of RA was 7.8 years. Extraarticular symptoms were revealed in 23 patients. 18 patients had arterial hypertension. 14 had steroid dependence. 11 patients had chronic nephropathy without kidney failure. 3 patients had secondary amyloidosis. IRHD was studied by means of renal functional reserve (RFR). RSR was studied by means of dynamic evaluation of glomerulofiltration with oral protein tests $(0.7 \mathrm{gr}$ of proteins per $1 \mathrm{~kg}$ of weight).

Results Disorders of IRHD (RFR $<5 \%$ ) were revealed in 17 RA patients including 3 patients with secondary amyloidosis. Of note are the following clinical features of this group: in 11 patients, duration of RA was more than 12 years; 12 patients had other extra articular symptoms and arterial hypertension; IRHD disorders were revealed in 5 patients who had no clinical and laboratory renal abnormalities. Those 5 patients had preexisting arterial hypertension, extra articular symptoms and RA duration was more than 10 years.

Conclusion IRHD disorders were revealed in severe cases of RA with signs of nephropathy. However, our findings of RFR disorders in patients, who had no nephropathy, required evaluation and estimation of IRHD in patients with RA duration over 10 years, associated arterial hypertension and extra articular symptoms.

\section{AB0040 THE INFLUENCE OF THE WAR CONDITIONS ON THE TREATMENT COURSE OF RHEUMATHOID ARTHRITIS}

N Kapidzic-Basic, H Seleskovic, S Kikanovic, S Mulic. Rheumathology, Clinic for Physical Medicine and Rehabilitation, Tuzla, Bosnia and Herzegovina

\subsection{6/annrheumdis-2001.1005}

Background Complicated therapy of the rheumatoid arthritis does not always give satisfying results so there is an opinion that the disease progresses with or without the treatment. During the war in Bosnia and Herzegovina $(\mathrm{BiH})$ neither diagnostic nor therapy were possible and difficulties went on after the war. Humanitarian aid brought only certain amount of medications from the NSAIDs group, and DMRADs were used rarely.

Objectives The aim of this work was to determine the severity of the change on locomotion system of RA patients who did not take DMARDs therapy during the war and to determine functional disability of those patients.

Methods Examination was conducted on 100 RA patients (according to modified ACR criteria) who had no therapy, but occasional NSAIDs during the 6 year period, nor physical therapy. Control group was 40 RA patients who lived outside of $\mathrm{BiH}$ during the war and who had taken DMARDs and physical therapy. Both groups were comparable with the length of the disease. The activity of the disease was evaluated (ESR, CRP, morning stiffness, visual analogue scale of pain, Ritchie index of joints sensitivity) as well as functional state index measured by HAQ, range of motion (ROM) and radiological examination.

Only one part of this large study will be presented here.

Results Mean duration of the disease was 12,1 years (SD 8,3). According to HAQ three groups were made: mild disability 0-1 (11\% of patients), moderate 1,01-2.0 (40\% of patients) and severe $2,01-3$ (49\%). 4\% of patients had no movement. HAQ results of the control group were following: $67,5 \%$ of patients were in the I group, $30 \%$ patients were in the II group and $2,5 \%$ of patients were in the III group. In the study of Wolfe et al. ${ }^{1} 43,25 \%$ patients were in the I group, $42,5 \%$ of patients were in the II group and $14,5 \%$ of patients were in the III group. And all other parameters were worse than the ones in the control group.

Conclusion It is obvious that disease strongly progresses without the usage of the drugs and physical therapy. More than half of the patients in the examined group were dependable on other people's help. Problems with the therapy of RA patients do not end with the end of the war because inhabitance became poor and the RA therapy is very expensive for the most patients. 


\section{REFERENCE}

1 Wolfe F, Kleinheksel SM, Cathey MA, Hawley D, Spitz P, Fries J. The clinical value of the stanford health assessment questionnaire functional disability index in patients with rheumatoid arthritis. J Rheumatol. 1988;15:10

\section{AB0041 COMPARISON OF ULTRASOUND FINDIGS OF KNEE JOINT SYNOVITIS AND DISEASE ACTIVITY IN RHEUMATOID ARTHRITIS PATIENTS}

VD Skakic. Rheumatology, Institute of Rheumatology "Niska Banja", Nis, Yugoslavia

10.1136/annrheumdis-2001.1006

Background Proliferative synovitis is very common finding in patients with rheumatoid arthritis (RA). Among imaging methods ultrasound is very useful instrument for detection of synovial abnormalities. Using this method we can measure thickness of synovium, it's morphology and localisation. During examination we also can detect joint effusion in knee and presence of Baker's in popliteal fossa. As a sign of synovial inflammation we can detect enhanced blood flow in proliferated synovium.

Objectives The aim of our study was to detect and measure the thickness of synovial proliferated tissue in suprapatellar recess and to try to find correlation between this finding and disease activity. We also used power doppler to observe blood flow in small vessels of synovial tissue.

Methods In our study we included 20 patients with clinically affected both knees. Using modern equipment for ultrasound examination (Acceuson Sequoia 5-8 MHz with power doppler), we measured thickness of the synovium in the middle of suprapatellar recess in longitudinal approach. We also detected presence of joint effusion as well as Baker's cyst in popliteal fossa. Disease activity was estimated by sedimentation rate.

Results We found the thickness of synovial tissue range 1, 3-6 $\mathrm{mm}$ (X average $=3,6 \mathrm{~mm}$ ). Joint effusion was presented in all patients. In $46 \%$ of patients we found Baker's cyst with the same synovial pattern. Sedimentation rate in our patients was ranged $19-110 / \mathrm{h}$. We didn't find any significant correlation between synovial thickness and such estimated disease activity. We also found presence of extensive blood flow in small vessels of synovium.

Conclusion Ultrasound is very objective instrument for detection and measuring of synovial proliferation. This information is useful for practicioner to indicate corticosteroidal injections, synoviorthesis or surgical synovioctomy. This method is also necessary to estimate the results of those procedures.

\section{REFERENCES}

1 Strome GM, Bouffard JA, van Holsbeek M. Synovial abnormalities. In: Fornage BD, ed. Muskuloskeletal ultrasound. Churchill Livingstone, New York, Edinburgh, London, Melbourne, Tokyo, 1995:203

2 Cozzi, et al. Ultarsound in monitoring knee joint synovitis [abstract]. Arthritis Rheum. 1998;41(Suppl 9):S50

3 Wolfgang $A$, et al. Color Duplex ultrasonography to detect pannus in knee joint effusion [abstract]. Arthritis Rheum. 1998;41(Suppl 9):S49

4 Helbich TH, et al. Baker's cysts ultrasonographic diagnosis. Rheumatol Eur. 1997;26(3):96-9

\section{AB0042 STRUCTURE OF RENAL DAMAGE IN RHEUMATOID ARTHRITIS}

RM Balabanova, IB Vinogradova, VI Mukhorin, VE Briginevich. Department of Rheumatology, Institute of Rheumatology, Moscow, Russia
Background Renal damage is one of most unfavourable prognostic factors in rheumatoid arthritis (RA). Most frequent pathology is renal amyloidosis. Rheumatic glomerulonephritis as a systemic manifestation of RA is infrequent. Important place belongs to renal exacerbations due to NSAIDs treatment and basic drugs.

Objectives To determine the character of renal damage in RA by the data of biopsy material.

Methods In the period from 1998 to 2000 in Rheumatological department of Ulianovsk Regional Hospital 10 RA pts with nephropathy symptoms were examined: proteinuria, azotemia, nephrotic syndrome with median disease duration of $17.7 \pm 5.1$ years. Appearing of symptoms of renal pathology was in $10.7 \pm$ 3.5 years from RA onset. Pts did not have basic therapy; according to their condition - only NSAIDs (Diclofenac, Indomethacin). All pts had closed renal biopsy.

Results According to data of hystological analysis 4 pts demonstrated amyloid lesion, 4 - interstitial nephritis, 1 - mesangioproliferative glomerulonephritis, 1 - combination of amyloidosis and interstitial nephritis. In two cases renal damage was the reason for lethal outcome.

Conclusion Absence of basic therapy for a long period of time of the disease results in the development of extraarticular manifestations and RA complication - amyloid renal damage.

\section{AB0043 ANTI-FILAGGRIN AUTOANTIBODIES ARE NOT PREDICTIVE OF RADIOLOGICAL PROGRESSION IN RHEUMATOID ARTHRITIS (RA) - RESULTS OF A 3-YEAR LONGITUDINAL PROSPECTIVE STUDY FROM A POPULATION BASED-RECRUITMENT OF 127 RA}

${ }^{1} O$ Vittecoq, ${ }^{2} \mathrm{~B}$ Inçaurgarat, 'S Pouplin, ${ }^{3} \mathrm{~J}$ Legoedec, ${ }^{2} \mathrm{O}$ Letourneur, ${ }^{2} \mathrm{D}$ Rolland, ${ }^{2} \mathrm{G}$ Gervasi, ${ }^{1} \mathrm{~K}$ Krzanowska, ${ }^{4} \mathrm{JF}$ Ménard, ${ }^{5} \mathrm{~A}$ Gayet, ${ }^{2} \mathrm{M}$ Jolivet, ${ }^{3} \mathrm{~F}$ Tron, ${ }^{1} \mathrm{X}$ Le Loët. ${ }^{1}$ Rhumatologie; ${ }^{2}$ BioMérieux, SA, Marcy I'Etoile, France; ${ }^{3}$ Immunology, INSERM U519, Rouen; ${ }^{4}$ Biométrie-Biostatistique; ${ }^{5}$ Collège Rhumatologues Haute Normandie, INSERM U519

\subsection{6/annrheumdis-2001.1008}

\section{Background}

Objectives To evaluate the predictive value of autoantibodies (Ab) directed against citrullinated recombinant rat filaggrin (ACRFA) detected by a new ELISA for prognosis in a cohort of community cases of RA.

Methods 127 patients (mean age: $50.5 \mathrm{yr}, \mathrm{F} / \mathrm{M}$ : 2.9) with early RA (median disease duration: $2 \mathrm{yr}$ ) were enrolled prospectively in 1996 (T1), primarily from a population based-recruitment (80\%), and were followed until 1999 (T2). At T1 were tested rheumatoid factors determined by the latex fixation test (LFT) and anti-filaggrin Abs identified by different assays, i.e. anti-keratin $\mathrm{Ab}$ (AKA), and anti-perinuclear factor (APF) by indirect immunofluorescence, ACRFA by an ELISA test whose results are expressed as the difference of OD values given by sera tested against the citrullinated and non-citrullinated forms of filaggrin. At T1 and T2: radiographs of the hands and wrists. Prognosis was defined by (1) radiological damage (van der Heijde modified Sharp method) at T2; (2) progression of radiological damage between $\mathrm{T} 1$ and $\mathrm{T} 2$.

Results At T1: RA had mild activity (Ritchie articular index: 11/ 78, mean CRP: $15 \mathrm{mg} / \mathrm{l}$ ), mild functional disability (HAQ: 0.8/ 3), mild X-ray destruction (Sharp: 9.2/280); 96\% of patients were treated at T1 (DMARDs: 95\%; prednisone: 72\%); frequency of LFT, AKA, APF and ACRFA were respectively: 50\%, 33\%, 45\% and 45\%. At T2: total Sharp score: 22.8/280. The only parameter at T1 associated with a higher Sharp score at T2 